\title{
Tipologi Pengembangan Wisata Berdasarkan Konsep Butler \\ (Studi Kasus : Kabupaten Mojokerto)
}

\author{
Ema Umilia ${ }^{1}$ \\ ${ }^{1}$ Urban and Regional Planning Department, Institut Teknologi Sepuluh Nopember, Indonesia \\ Umilia84@gmail.com
}

\begin{abstract}
ABSTRAK
Kabupaten Mojokerto memiliki potensi pariwisata yang besar. Sebagian wilayahnya berada di dataran tinggi yang memiliki banyak peninggalan purbakala dari periode HinduBudha. Kabupaten Mojokerto juga memiliki banyak benda purbakala peninggalan jaman Kerajaan Majapahit yang terletak di Trowulan. Tidak semua obyek wisata di Kabupaten Mojokerto terkelola dengan baik. Beberapa diantaranya masih belum dikelola dan belum dioptimalkan. Kondisi tersebut menyebabkan obyek wisata di Kabupaten Mojokerto memiliki fase perkembangan yang berbeda-beda. Dengan demikian, diperlukan suatu pengelompokkan obyek wisata berdasarkan fase perkembangan wisata seperti yang dikemukakan dalam Konsep Butler.

Mojokerto Regency has large tourism potential. Some of the area being on the upland which has many relics from a period of Hindu-Budha. Mojokerto Regency also has a lot of Majapahit Kingdom's archaeological relic which is located in Trowulan. Not all tourist destinations in Mojokerto managed properly. Some of them are still undeveloped and not yet optimized. This condition is causing the tourist destination in Mojokerto having different phase. Thus, it is needed for clustering the tourist destination based on the tourism development phase as described in the Concept of Butler.
\end{abstract}

Kata Kunci: Fase Perkembangan, Tipologi, Wisata 


\section{PENDAHULUAN}

Sektor pariwisata merupakan potensi yang dimiliki oleh setiap daerah dan dapat dikembangkan secara maksimal guna meningkatkan pendapatan daerah. Sektor pariwisata juga merupakan salah satu sektor pembangunan di bidang ekonomi yang diharapkan dapat memberikan kontribusi yang besar terhadap perekonomian daerah. Usaha untuk mengembangkan sektor pariwisata didukung dengan adanya Undang-Undang Nomor 10 Tahun 2009 tentang Kepariwisataan. Pengelolaan sektor pariwisata yang baik dapat menjadikan sektor wisata sebagai salah satu industri yang prospektif dan mempunyai multiplier efek bagi perkembangan suatu wilayah.

Kabupaten Mojokerto memiliki potensi pariwisata yang besar, diantaranya wisata alam, purbakala, dan budaya. Akan tetapi, jenis wisata yang lebih dominan ialah wisata alam dan purbakala. Sebagian wilayah Kabupaten Mojokerto berada di dataran tinggi atau pegunungan. Beberapa obyek wisata alam yang telah berkembang di Kabupaten Mojokerto ialah Air Terjun Dlundung, Wana Wisata Padusan Pacet, Air Terjun Coban Canggu, Kolam Pemandian Air Panas Padusan Pacet, PPLH Seloliman, Pemandian Ubalan Pacet, dan lain-lain. Selain itu, menurut sejarahnya, Kabupaten Mojokerto pernah menjadi pusat Kerajaan Majapahit yang telah berdiri sejak abad XIII-XIV century. Bukti fisik peninggalan jaman Kerajaan Majapahit terdapat di wilayah Trowulan. Beberapa situs tersebut telah dilindungi sebagai benda cagar budaya dan ditetapkan sebagai obyek wisata, diantaranya Candi Bajang Ratu, Bangkal, Brahu, Gentong, Kedaton, Minak Jinggo, dan banyak candi lainnya. Selain itu juga terdapat wisata buatan, seperti Ekowisata Tanjungan, Pacet Mini Park, Waterland, Taman Wisata Rolak Songo, dan banyak lainnya.

Ada pula potensi wisata di Kabupaten Mojokerto yang belum tereksplor dengan optimal, seperti di kawasan kaki Gunung Penanggungan.
Kawasan kaki Gunung Penanggungan memiliki potensi alam berupa keindahan gunung dan pemandangan alami. Selain itu, di kaki Gunung Penanggungan juga ditemukan berbagai peninggalan purbakala, seperti candi, pertapaan, dan pertirtaan dari periode Hindu-Budha di Jawa Timur. Menurut sejarahnya, gunung ini merupakan gunung suci yang memiliki kaitan erat dengan tradisi pemujaan kepada para Dewa atau arwah leluhur. Sehingga banyak dijumpai bangunan suci yang sudah ada sejak masa pra Hindu-Buddha dan merupakan tempat pemujaan.

Tidak hanya memiliki potensi, sektor pariwisata di Kabupaten Mojokerto juga memiliki beberapa permasalahan yang menyebabkan pengembangan dan pengelolaan pariwisatanya kurang optimal. Tidak semua obyek wisata memiliki daya tarik dan atraksi wisata yang dapat menarik banyak wisatawan untuk berkunjung. Selain itu, masih terdapat beberapa obyek wisata yang belum dilengkapi dengan infrastruktur pendukung, seperti jaringan jalan yang baik. Beberapa jenis wisata, khususnya wisata alam, juga menyebabkan turunnya kualitas lingkungan.

Berdasarkan hal tersebut, dapat dilihat adanya kesenjangan pada obyekobyek wisata di Kabupaten Mojokerto. Sebagian obyek wisata sudah terkelola dengan baik, sebagian lainnya masih belum terkelola secara optimal, sedangkan sebagian lainnya masih belum dikelola sama sekali. Dengan demikian, diperlukan suatu perumusan tipologi untuk mengelompokkan obyek wisata agar pengelolaan ke depannya bisa dilakukan dengan optimal. Pengelompokkan didasarkan pada teori yang dikemukakan oleh Butler mengenai fase perkembangan wisata. Obyek wisata yang berada pada fase yang sama akan dikelompokkan dalam satu kelompok. Dengan demikian, nantinya dapat dirumuskan penanganan yang tepat untuk masing-masing kelompok.

\section{METODE}


Metode yang digunakan ialah deskriptif statistik dan komparatif. Analisis data deskriptif atau statistik deskriptif bertujuan untuk memberikan deskripsi mengenai subjek penelitian berdasarkan data dari variabel yang diperoleh (Azwar, 1998). Data-data dideskripsikan untuk menjadi sebuah informasi yang lebih jelas, dalam bentuk persentase, proporsi, atau frekuensi yang divisualisasikan melalui grafik dan chart. Pendeskripsian juga dilakukan dengan perbandingan atau komparasi.

\section{HASIL}

Butler mengemukakan konsep tentang fase perkembangan pariwisata yang terbagi dalam 7 fase, yaitu exploration, involvement phase (keterlibatan), development phase (pembangunan), consolidation phase (konsolidasi), stagnation phase (stagnasi), decline phase (penurunan), dan rejuvenation phase (peremajaan). Untuk lebih jelasnya dapat dilihat pada gambar berikut:

Tabel 1. Penjelasan Variabel dalam Tahapan Perkembangan

\begin{tabular}{|c|c|c|c|c|c|c|c|c|}
\hline No & Tahapan & Atraksi Wisata & $\begin{array}{c}\text { Ketersediaan } \\
\text { Fasilitas } \\
\text { Penunjang }\end{array}$ & $\begin{array}{l}\text { Promosi } \\
\text { Wisata }\end{array}$ & $\begin{array}{l}\text { Produk } \\
\text { Wisata }\end{array}$ & $\begin{array}{c}\text { Jumlah } \\
\text { Pengunjung }\end{array}$ & $\begin{array}{c}\text { Penyedia } \\
\text { Jasa } \\
\text { Pariwisata }\end{array}$ & $\begin{array}{l}\text { Investasi } \\
\text { Luar }\end{array}$ \\
\hline 1 & Exploration & $\begin{array}{l}\text { Masih tersedia } \\
\text { atraksi alam } \\
\text { (kebudayaan } \\
\text { dan } \\
\text { pemandangan) }\end{array}$ & $\begin{array}{l}\text { Aksesibilitas } \\
\text { masih sulit } \\
\text { dicapai }\end{array}$ & Belum ada & $\begin{array}{l}\text { Masih berupa } \\
\text { produk alami } \\
\text { yang tersedia, } \\
\text { belum } \\
\text { dikembangkan }\end{array}$ & Masih sedikit & Belum ada & Belum ada \\
\hline 2 & Involvement & $\begin{array}{l}\text { Masih berfokus } \\
\text { pada } \\
\text { pengembangan } \\
\text { atraksi alami } \\
\text { yang dimiliki }\end{array}$ & $\begin{array}{l}\text { Berbagai } \\
\text { fasilitas } \\
\text { penunjang } \\
\text { mulai } \\
\text { disediakan, } \\
\text { umumnya oleh } \\
\text { masyarakat } \\
\text { lokal }\end{array}$ & $\begin{array}{l}\text { Mulai ada } \\
\text { promosi }\end{array}$ & $\begin{array}{l}\text { Mulai } \\
\text { dikembangkan }\end{array}$ & $\begin{array}{l}\text { Peningkatan } \\
\text { jumlah } \\
\text { kunjungan } \\
\text { wisatawan }\end{array}$ & $\begin{array}{l}\text { Masyarakat } \\
\text { lokal mulai } \\
\text { berperan } \\
\text { dalam } \\
\text { menyediaka } \\
\text { n jasa } \\
\text { pariwisata }\end{array}$ & Belum ada \\
\hline 3 & Development & $\begin{array}{l}\text { Atraksi buatan } \\
\text { mulai } \\
\text { dikembangkan } \\
\text { untuk } \\
\text { mendukung } \\
\text { atraksi alami }\end{array}$ & $\begin{array}{l}\text { Fasilitas lokal } \\
\text { sudah tersisih } \\
\text { atau digantikan } \\
\text { oleh fasilitas } \\
\text { yang benar- } \\
\text { benar touristic } \\
\text { dengan standar } \\
\text { internasional }\end{array}$ & $\begin{array}{l}\text { Promosi } \\
\text { semakin } \\
\text { intensif }\end{array}$ & $\begin{array}{l}\text { Mulai ada } \\
\text { beberapa } \\
\text { produk wisata: } \\
\text { a. Aspek } \\
\text { lingkungan } \\
\text { alamian } \\
\text { b. Aspek } \\
\text { lingkungan } \\
\text { buatan }\end{array}$ & $\begin{array}{l}\text { Jumlah } \\
\text { pengunjung } \\
\text { sedikit } \\
\text { bertambah }\end{array}$ & $\begin{array}{l}\text { Masyarakat } \\
\text { lokal dan } \\
\text { pihak luar }\end{array}$ & $\begin{array}{l}\text { Investasi } \\
\text { dari luar } \\
\text { mulai } \\
\text { masuk }\end{array}$ \\
\hline 4 & $\begin{array}{l}\text { Consolidatio } \\
n\end{array}$ & $\begin{array}{l}\text { Memiliki atraksi } \\
\text { alami dan } \\
\text { atraksi buatan } \\
\text { yang }\end{array}$ & $\begin{array}{l}\text { Fasilitas lama } \\
\text { sudah } \\
\text { ditinggalkan }\end{array}$ & $\begin{array}{l}\text { Promosi } \\
\text { semakin } \\
\text { gencar dan } \\
\text { diperluas }\end{array}$ & $\begin{array}{l}\text { Produk wisata } \\
\text { semakin } \\
\text { beragam: } \\
\text { a. Aspek }\end{array}$ & $\begin{array}{l}\text { Jumlah } \\
\text { pengunjung } \\
\text { meningkat } \\
\text { namun masih }\end{array}$ & $\begin{array}{l}\text { Peran } \\
\text { investor luar } \\
\text { semakin } \\
\text { besar dalam }\end{array}$ & $\begin{array}{l}\text { Investor- } \\
\text { investor } \\
\text { dari luar } \\
\text { semakin }\end{array}$ \\
\hline
\end{tabular}

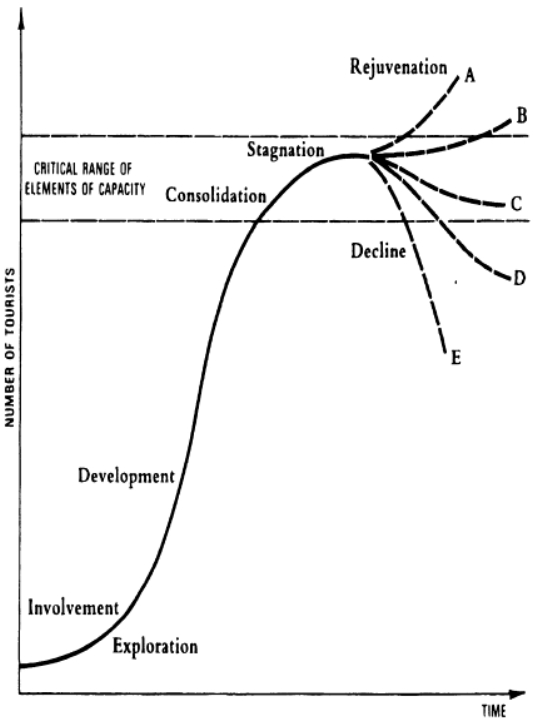

Sumber : Butler (1980)

\section{Gambar 1. Fase Perkembangan Wisata}

Berdasarkan konsep diatas, dilakukan pendefinisian variabel terkait fase perkembangan wisata yang dapat dilihat pada tabel berikut: 


\begin{tabular}{|c|c|c|c|c|c|c|c|c|}
\hline No & Tahapan & Atraksi Wisata & $\begin{array}{l}\text { Ketersediaan } \\
\text { Fasilitas } \\
\text { Penunjang }\end{array}$ & $\begin{array}{c}\text { Promosi } \\
\text { Wisata }\end{array}$ & $\begin{array}{l}\text { Produk } \\
\text { Wisata }\end{array}$ & $\begin{array}{c}\text { Jumlah } \\
\text { Pengunjung }\end{array}$ & $\begin{array}{l}\text { Penyedia } \\
\text { Jasa } \\
\text { Pariwisata }\end{array}$ & $\begin{array}{l}\text { Investasi } \\
\text { Luar }\end{array}$ \\
\hline & & $\begin{array}{l}\text { dikembangkan } \\
\text { untuk } \\
\text { mendukung } \\
\text { atraksi alami }\end{array}$ & & & $\begin{array}{l}\text { lingkungan } \\
\text { alamian } \\
\text { b. Aspek } \\
\text { lingkungan } \\
\text { buatan } \\
\text { c. Aspek } \\
\text { sarana } \\
\text { prasarana } \\
\text { wisata }\end{array}$ & $\begin{array}{l}\text { pada tingkat } \\
\text { lebih rendah }\end{array}$ & $\begin{array}{l}\text { menyediaka } \\
\mathrm{n} \text { jasa wisata }\end{array}$ & $\begin{array}{l}\text { bertambah } \\
\text { (dipegang } \\
\text { oleh } \\
\text { jaringan } \\
\text { internasion } \\
\text { al) }\end{array}$ \\
\hline 5 & Stagnation & $\begin{array}{l}\text { Atraksi buatan } \\
\text { sudah } \\
\text { mendominasi } \\
\text { atraksi asli alami } \\
\text { (baik budaya } \\
\text { maupun alam) } \\
\text { sehingga citra } \\
\text { awal sudah } \\
\text { mulai meluntur, }\end{array}$ & $\begin{array}{l}\text { Berbagai } \\
\text { fasilitas } \\
\text { dikembangkan } \\
\text { sehingga } \\
\text { melampaui } \\
\text { daya dukung }\end{array}$ & $\begin{array}{l}\text { Promosi } \\
\text { tetap } \\
\text { berjalan }\end{array}$ & $\begin{array}{l}\text { Produk wisata } \\
\text { tidak saling } \\
\text { menunjang } \\
\text { melainkan } \\
\text { saling } \\
\text { mendominasi }\end{array}$ & $\begin{array}{l}\text { Jumlah } \\
\text { pengunjung } \\
\text { stagnan }\end{array}$ & $\begin{array}{l}\text { Investor luar } \\
\text { berperan } \\
\text { dalam } \\
\text { menyediaka } \\
\text { n jasa wisata }\end{array}$ & $\begin{array}{l}\text { Investor- } \\
\text { investor } \\
\text { dari luar } \\
\text { (dipegang } \\
\text { oleh } \\
\text { jaringan } \\
\text { internasion } \\
\text { al) }\end{array}$ \\
\hline 6 & Decline & $\begin{array}{l}\text { Atraksi wisata } \\
\text { semakin } \\
\text { menurun dan } \\
\text { tidak } \\
\text { memberikan } \\
\text { daya tarik wisata }\end{array}$ & $\begin{array}{l}\text { Banyak } \\
\text { fasilitas } \\
\text { pariwisata } \\
\text { sudah } \\
\text { dialihkan } \\
\text { fungsinya } \\
\text { untuk kegiatan } \\
\text { non-pariwisata }\end{array}$ & $\begin{array}{l}\text { Promosi } \\
\text { semakin } \\
\text { berkurang }\end{array}$ & $\begin{array}{l}\text { Produk wisata } \\
\text { semakin } \\
\text { berkurang dan } \\
\text { kurang } \\
\text { diminati lagi }\end{array}$ & $\begin{array}{l}\text { Kunjungan } \\
\text { tertinggi } \\
\text { hanya pada } \\
\text { akhir pekan }\end{array}$ & $\begin{array}{l}\text { Penyedia } \\
\text { jasa } \\
\text { pariwisata } \\
\text { menurun }\end{array}$ & $\begin{array}{l}\text { Investasi } \\
\text { dai luar } \\
\text { berkurang }\end{array}$ \\
\hline 7 & Rejuvenation & $\begin{array}{l}\text { Atraksi wisata } \\
\text { mulai } \\
\text { dikembangkan } \\
\text { lagi dengan } \\
\text { menambahkan } \\
\text { inovasi }\end{array}$ & $\begin{array}{l}\text { Fasilitas } \\
\text { penunjang } \\
\text { mulai } \\
\text { ditingkatkan } \\
\text { lagi }\end{array}$ & $\begin{array}{l}\text { Promosi } \\
\text { mulai } \\
\text { digencarka } \\
\text { n lagi }\end{array}$ & $\begin{array}{l}\text { Ada inovasi } \\
\text { dalam } \\
\text { pengembangan } \\
\text { produk baru }\end{array}$ & $\begin{array}{l}\text { Jumlah } \\
\text { pengunjung } \\
\text { mulai } \\
\text { meningkat } \\
\text { lagi }\end{array}$ & $\begin{array}{l}\text { Penyedia } \\
\text { jasa } \\
\text { pariwisata } \\
\text { bermunculan } \\
\text { kembali }\end{array}$ & $\begin{array}{l}\text { Investasi } \\
\text { dari luar } \\
\text { mulai ada } \\
\text { dan } \\
\text { bertambah } \\
\text { lagi }\end{array}$ \\
\hline
\end{tabular}

Sumber: Hasil Analisa, 2016

Berdasarkan variabel diatas, maka obyek wisata di Kabupaten Mojokerto dikelompokkan sebagai berikut :

Tabel 2. Pengelompokan Obyek Wisata di Kabupaten Mojokerto berdasarkan Tahapan Perkembangan

\begin{tabular}{|c|l|l|l|l|}
\hline No & Tahapan & Dikelola Pemda (A) & Dikelola non Pemda (B) & Belum Dikelola Lembaga/Instansi (C) \\
\hline 1 & Exploration & 1. Ekowisata & - & Air Terjun Grenjeng \\
& & Tanjungan & & 1. Solokendit \\
& & & 2. Gunung Batuk \\
& & & & 3. Gunung Pundak \\
& & & 4. Gunung Welirang \\
& & & 5. Gua Gembyang \\
& & & 6. Gua Lowo \\
& & & 7. Wanawisata Bendulan \\
& & & 8. Sumber Air Jubel \\
& & & 9. Krapyak \\
& & & 10. Air Terjun Coban Kembar Watu Ondo \\
& & & 11. Candi Sumur Gantung \\
& & & 12. Situs Yoni Bre Kahuripan \\
& & & 13. Situs Pithecantropus \\
& & & 14. Petilasan Jago Panji Laras \\
& & & 15. Petilasan Gajah Mada Jabung \\
& & & 16. Umpak Batu Yoni Lebak Jabung \\
\hline
\end{tabular}




\begin{tabular}{|c|c|c|c|c|}
\hline No & Tahapan & Dikelola Pemda (A) & Dikelola non Pemda (B) & Belum Dikelola Lembaga/Instansi (C) \\
\hline & & & & $\begin{array}{l}\text { 17. Situs Prasasti Kembangsore } \\
\text { 18. Waduk Cinandang } \\
\text { 19. Lengkong Baru } \\
\text { 20. Taman Wisata Rolak Songo } \\
\text { 21. Kolam Renang Klinterejo } \\
\text { 22. SPN Bangsal } \\
\text { 23. Waterland } \\
\text { 24. Kolam Renang MK Tirta } \\
\text { 25. Randugenengan } \\
\text { 26. Pekukuhan } \\
\text { 27. Pondok Ikan } \\
\text { 28. Sumonggo Pinarak } \\
\text { 29. Made } \\
\text { 30. Bumi Perkemahan Desa Wisata Claket } \\
\text { 31. Makam Krapyah } \\
\text { 32. Makam Syech Mahmud } \\
\text { 33. Makam Tumenggung Prawirosono } \\
\text { 34. Makam Mbah Mendek } \\
\text { 35. Makam Ki Ageng Jabung }\end{array}$ \\
\hline 2 & Involvement & $\begin{array}{l}\text { 1. Pertirtaan Jolotundo } \\
\text { 2. Air Terjun Dlundung } \\
\text { 3. Air Terjun Coban } \\
\text { Canggu } \\
\text { 4. Musium Trowulan } \\
\text { 5. Siti Inggil } \\
\text { 6. Pemandian Ubalan } \\
\text { Pacet } \\
\end{array}$ & $\begin{array}{l}\text { 1. Wana Wisata Gunung } \\
\text { Penanggungan/PPLH } \\
\text { Seloliman } \\
\text { 2. Tahura RM. Surya } \\
\text { 3. Jasa Tirta } \\
\text { 4. Tirta Anandiri }\end{array}$ & - \\
\hline 3 & Development & $\begin{array}{l}\text { 1. Kolam/Pemandian } \\
\text { Air Panas Padusan } \\
\text { Pacet } \\
\text { 2. Wana Wisata } \\
\text { Padusan Pacet } \\
\text { 3. Makam Religius } \\
\text { Troloyo }\end{array}$ & $\begin{array}{l}\text { 1. Candi Bajang Ratu } \\
\text { 2. Candi Bangkal } \\
\text { 3. Candi Brahu } \\
\text { 4. Candi Gentong } \\
\text { 5. Candi Bejong/Jedong } \\
\text { 6. Candi Kedaton/Sumur } \\
\text { Upas } \\
\text { 7. Candi Kesimen } \\
\text { Tengah } \\
\text { 8. Candi Minak Jinggo } \\
\text { 9. Candi Pasetran } \\
\text { 10. Candi Tikus } \\
\text { 11. Candi Wringin } \\
\text { Lawang } \\
\text { 12. Kolam Segaran } \\
\text { 13. Kubur Panggung } \\
\text { 14. Makam Putri Campa } \\
\text { 15. Reco Lanang } \\
\text { 16. Reco Wedok } \\
\text { 17. Pendopo Agung } \\
\text { 18. Maha Vihara } \\
\text { Majapahit } \\
\text { 19. Pacet Mini Park }\end{array}$ & - \\
\hline 4 & Consolidation & - & - & - \\
\hline 5 & Stagnation & - & - & - \\
\hline 6 & Decline & $\begin{array}{l}\text { 1. Wana Wisata Watu } \\
\text { Blorok } \\
\text { 2. Api Alam Bekucuk }\end{array}$ & - & - \\
\hline 7 & Rejuvenation & - & - & - \\
\hline
\end{tabular}


Berdasarkan hasil analisa diatas, didapatkan 3 tipologi obyek wisata di Kabupaten Mojokerto berdasarkan fase perkembangannya. Untuk lebih jelasnya dapat dilihat pada penjelasan berikut:

\section{a. Tipologi A}

Tipologi A merupakan pengelompokkan obyek wisata yang dikelola oleh Pemda Mojokerto. Obyek wisata pada tipologi A berada pada tahap exploration, involvement, dan development. Obyek wisata pada Tipologi A yang berada dalam tahap exploration adalah Ekowisata Tanjungan. Kegiatan utama yang bisa dilakukan di Ekowisata Tanjungan ialah memancing karena terdapat waduk dan tambak didalamnya. Jika digrafikkan berdasarkan tahapan perkembangannya, Ekowisata Tanjungan sempat mengalami penurunan (decline) pada tahun 2012. Hal tersebut dapat dilihat dari jumlah pengunjung yang mengalami penurunan dari 11.653 (tahun 2011) menjadi 4.349 (tahun 2012); 5.389 (tahun 2013); dan 4.794 (tahun 2014). Saat ini, Ekowisata Tanjungan sedang dalam proses peningkatan untuk kembali pada tahap exploration. Berikut ini merupakan grafik perkembangan dan gambar obyek wisata:

\section{BAHASAN}

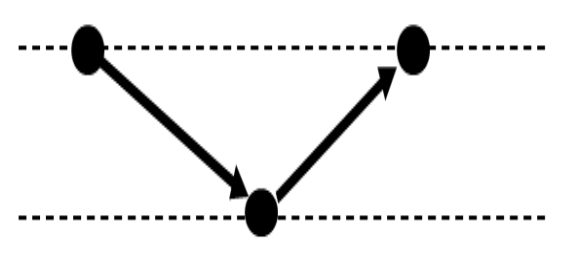

Sumber : Hasil Analisa, 2014

$$
\begin{gathered}
\text { Gambar 2. Grafik Perkembangan } \\
\text { Obyek Wisata Tipologi A pada } \\
\text { Tahap Exploration }
\end{gathered}
$$

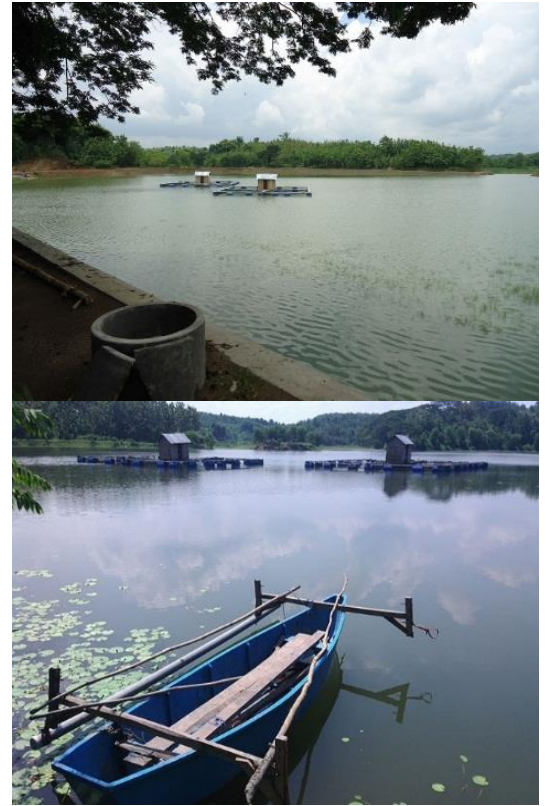

\section{Gambar 3. Ekowisata Tanjungan}

Sementara itu, obyek wisata pada Tipologi A yang berada dalam tahap involvement berjumlah 6 obyek, dengan rincian seperti yang tertera pada tabel diatas. Mayoritas merupakan obyek wisata alam yang memiliki atraksi wisata alami berupa air terjun, pegunungan, dan pertirtaan yang memiliki pemandangan indah. Obyek wisata dalam tahap ini telah dikelola dan mengalami peningkatan jumlah kunjungan wisatawan. Dalam pengelolaannya, terdapat peran serta masyarakat lokal, seperti dalam penyediaan berbagai fasilitas exploratipenunjang kegiatan pariwisata. Sedangkan promosi juga mulai digencarkan sehingga obyek-obyek wisata pada tahap ini mulai menjadi suatu destinasi wisata yang menarik. Berikut ini merupakan grafik perkembangan dan gambar obyek wisata:

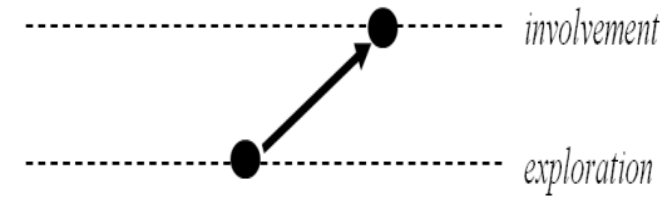

Sumber : Hasil Analisa, 2014

Gambar 4. Grafik Perkembangan Obyek Wisata 
Tipologi A pada Tahap Involvement

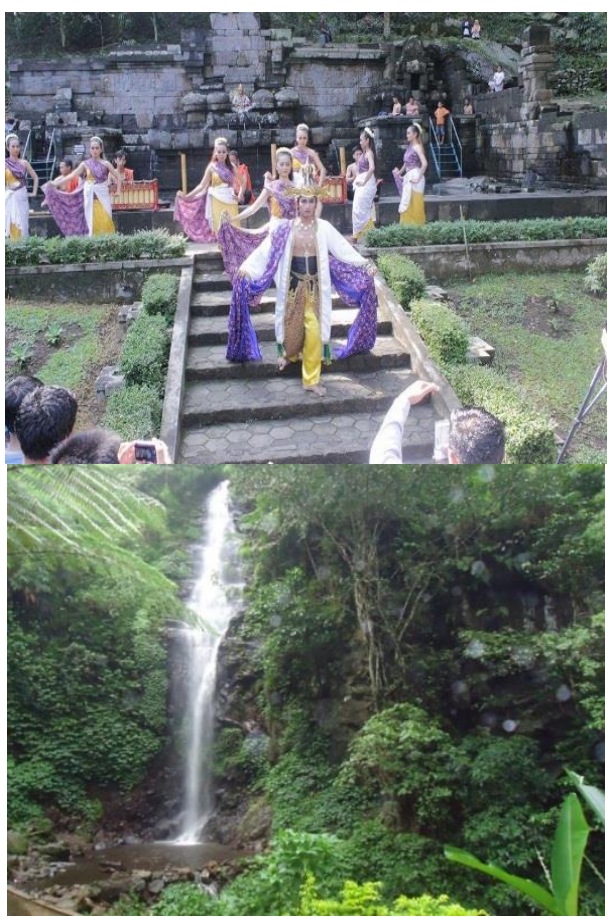

Gambar 5. Pertirtaan Jolotundo (kiri) dan Air Terjun Dlundung (kanan)

Selain itu juga terdapat obyek wisata pada Tipologi A yang berada pada tahap development, yaitu berjumlah 3 obyek, dengan rincian seperti yang tertera pada tabel diatas. Obyek wisata pada tahap ini ialah wisata alam dan wisata religi. Untuk wisata alam, telah dilengkapi dengan fasilitas penunjang wisata yang cukup memadai. Selain itu juga terdapat area bermain untuk anak-anak. Jumlah pengunjung obyek wisata yang berada pada tahap ini mengalami peningkatan selama 2 tahun terakhir. Pengunjungnya pun merupakan wisatawan domestik dan mancanegara. Sedangkan untuk wisata religi, yaitu Makam Religius Troloyo, juga telah mengalami peningkatan jumlah pengunjung pada tahun 2011-2013, yaitu dari 309.850 (tahun 2011); 446.569 (tahun 2012); dan 435.019 (tahun 2013). Berikut ini merupakan grafik perkembangan dan gambar obyek wisata:

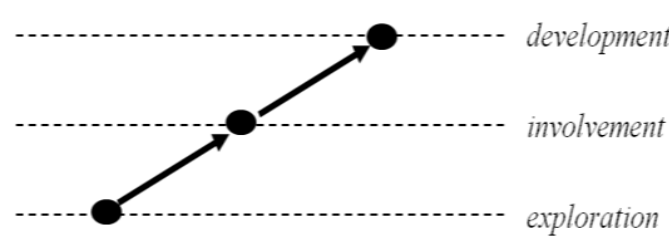

Sumber : Hasil Analisa, 2014

Gambar 6. Grafik Perkembangan Obyek Wisata Tipologi A pada Tahap Development

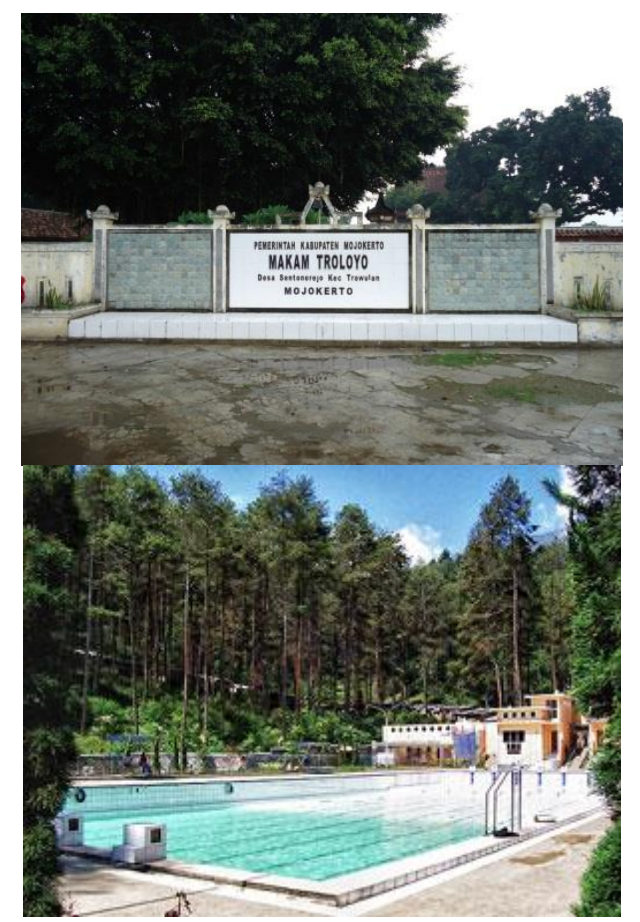

Gambar 7. Makam Troloyo (kiri) dan Wana Wisata Padusan (kanan)

Ada pula obyek wisata yang berada pada tahap decline, yaitu Wana Wisata Watublorok. Wana wisata ini dikelola oleh Perhutani. Wana wisata ini sempat ramai dikunjungi karena memiliki daya tarik berupa bongkahan batu singkapan geologi yang berwarna abu-abu muda dengan bercak (blorok) abu-abu tua. Warna bercak ini ialah bijih Xeolit yang terjebak dalam batuan kaolin. Obyek wisata ini berada di dalam hutan jati pegunungan kapur yang didalamnya terdapat tanaman kayu putih. Namun, siring dengan perkembangan zaman, obyek wisata ini mulai terabaikan sehingga banyak fasilitas yang rusak dan rapuh. Saat ini, wisatawan sudah beralih ke destinasi wisata baru. Banyak fasilitas 
pariwisata sudah dialihkan fungsinya untuk kegiatan non-pariwisata, sehingga destinasi semakin tidak menarik bagi wisatawan. Begitu pula dengan Api Alam Bekucuk. Berikut ini merupakan grafik perkembangan dan gambar obyek wisata:

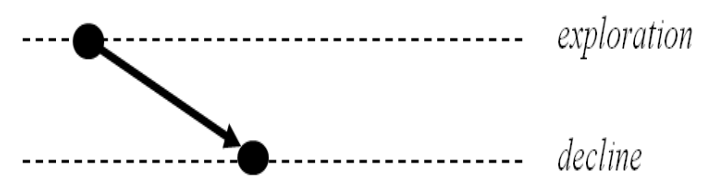

Sumber : Hasil Analisa, 2014

Gambar 8. Grafik Perkembangan

Obyek Wisata Tipologi $\mathrm{C}$ pada

Tahap Decline

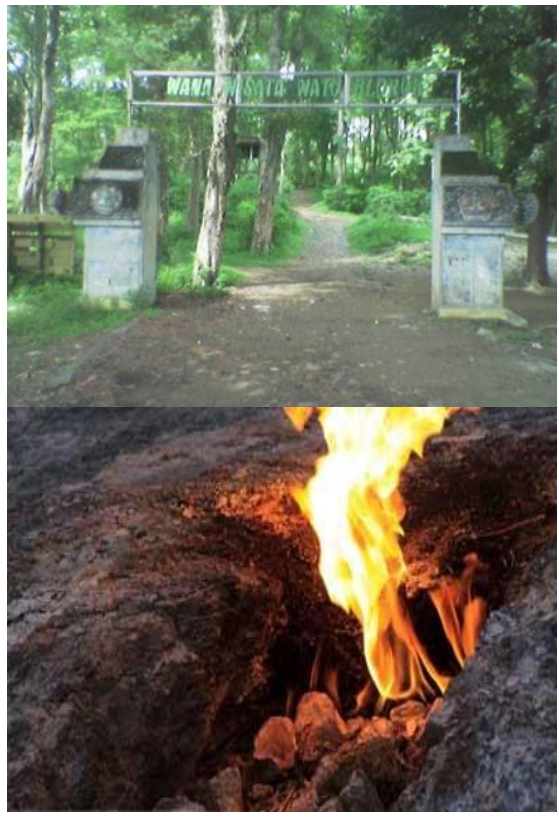

Gambar 9. Wana Wisata Watublorok (kiri) dan Api Alam Bekucuk (kanan)

\section{b. Tipologi B}

Tipologi B merupakan pengelompokkan obyek wisata yang dikelola oleh non Pemda Mojokerto, didalamnya termasuk BPCB Jawa Timur, Perhutani, swasta, dan lembaga masyarakat. Obyek wisata pada tipologi B berada pada tahap involvement dan development. Obyek wisata yang berada pada tahap involvement berjumlah 4 obyek, dengan rincian seperti pada tabel diatas. Dua diantaranya merupakan obyek wisata alam dengan fungsi pelestarian flora (Wana Wisata Gunung Penanggungan dan Tahura RM. Surya). Sementara dua lagi merupakan wisata buatan berupa pemandian (Jasa Tirta dan Tirta Anandiri). Obyek wisata dalam tahap ini masih berfokus pada pengembangan atraksi yang dimiliki. Dalam pengelolaannya, juga terdapat peran serta masyarakat lokal, misalnya penjual makanan dan minuman. Promosi mengenai obyek wisata ini masih terus dilakukan untuk menarik jumlah pengunjung. Berikut ini merupakan grafik perkembangan dan gambar obyek wisata:

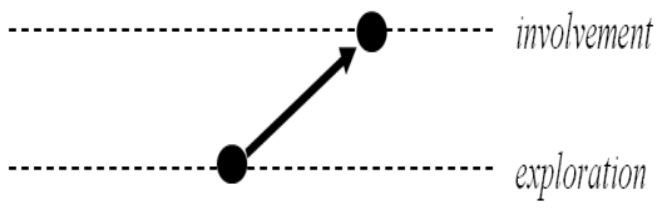

Sumber : Hasil Analisa, 2014

Gambar 10. Grafik Perkembangan Obyek Wisata Tipologi B pada Tahap Involvement

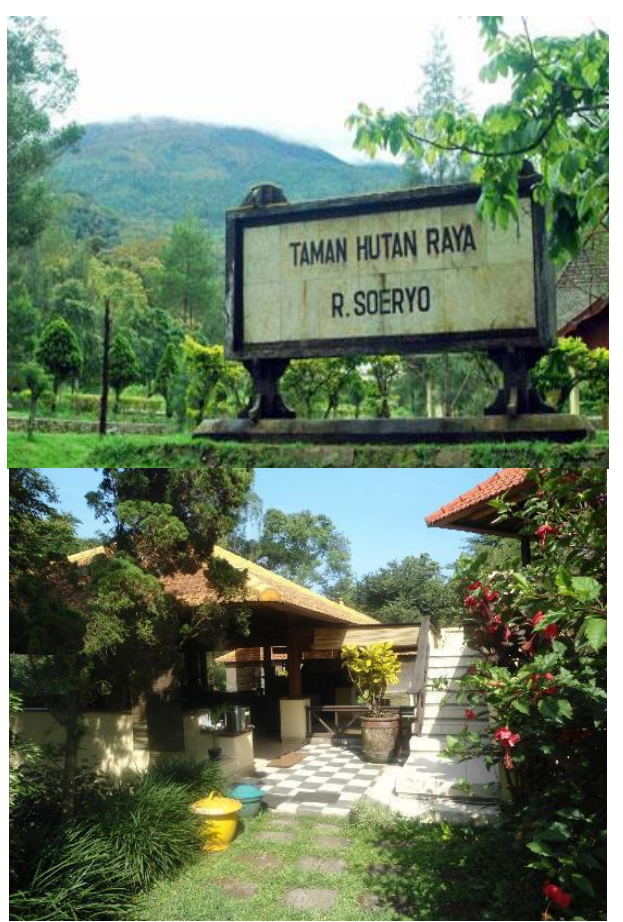

Gambar 11. Tahura R. Soeryo (kiri) dan PPLH Seloliman (kanan)

Selain itu juga terdapat obyek wisata pada Tipologi B yang berada 
pada tahap development, yaitu berjumlah 19 obyek, dengan rincian seperti yang tertera pada tabel diatas. Obyek wisata pada tahap ini merupakan situs-situs wisata purbakala peninggalan Kerajaan Majapahit yang memiliki atraksi wisata berupa kebudayaan, benda-benda tradisional, dan situs-situs bersejarah. Beberapa atraksi buatan sudah mulai dikembangkan untuk menambahkan atraksi yang asli alami, seperti taritarian dan berbagai pertunjukan lainnya. Obyek wisata pada tahap ini telah dilengkapi dengan fasilitas penunjang pariwisata. Jumlah pengunjung obyek wisata yang berada pada tahap ini mengalami peningkatan selama 2 tahun terakhir. Pengunjungnya pun merupakan wisatawan domestik dan mancanegara. Untuk lebih jelasnya dapat dilihat pada diagram berikut:

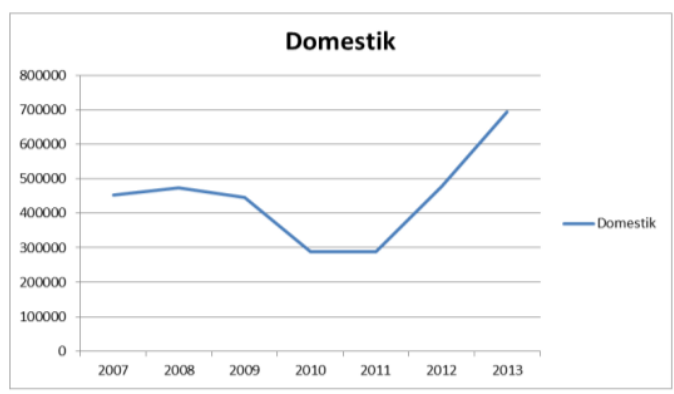

Sumber : BPCB Jawa Timur, 2014

Gambar 12. Perkembangan Jumlah Wisatawan Domestik Obyek Wisata Tipologi B pada Tahap Development

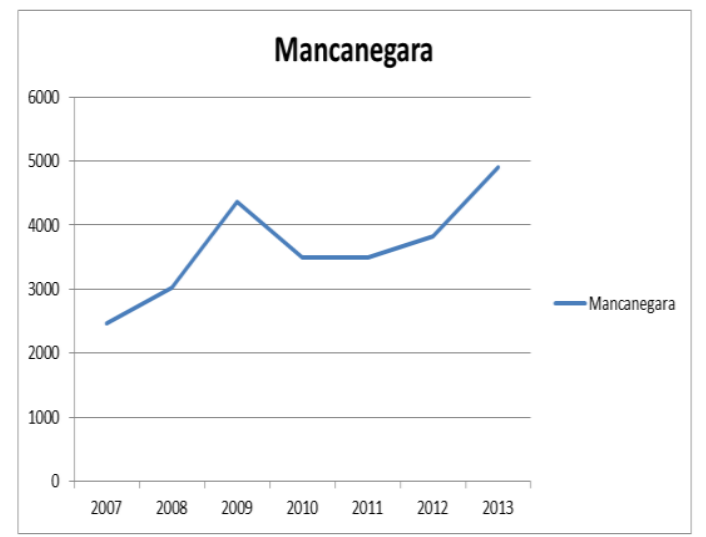

Sumber : BPCB Jawa Timur, 2014

Gambar 13. Perkembangan Jumlah Wisatawan Mancanegara Obyek Wisata
Tipologi B pada Tahap Development

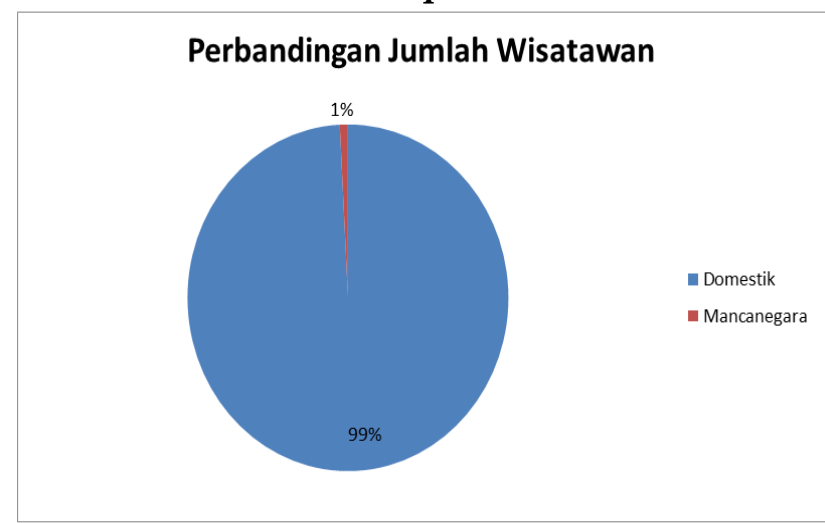

Sumber : BPCB Jawa Timur, 2014

Gambar 14. Perbandingan Jumlah Wisatawan Obyek Wisata Tipologi B pada Tahap Development

Sementara itu, grafik perkembangannya semakin meningkat, mulai dari tahap exploration yang telah dilewati, hingga memasuki tahap development. Berikut ini merupakan grafik perkembangannya:

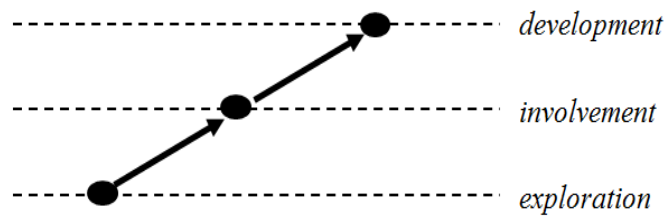

Sumber: Hasil Analisa, 2014

Gambar 15. Grafik Perkembangan Obyek Wisata Tipologi B pada Tahap Development 


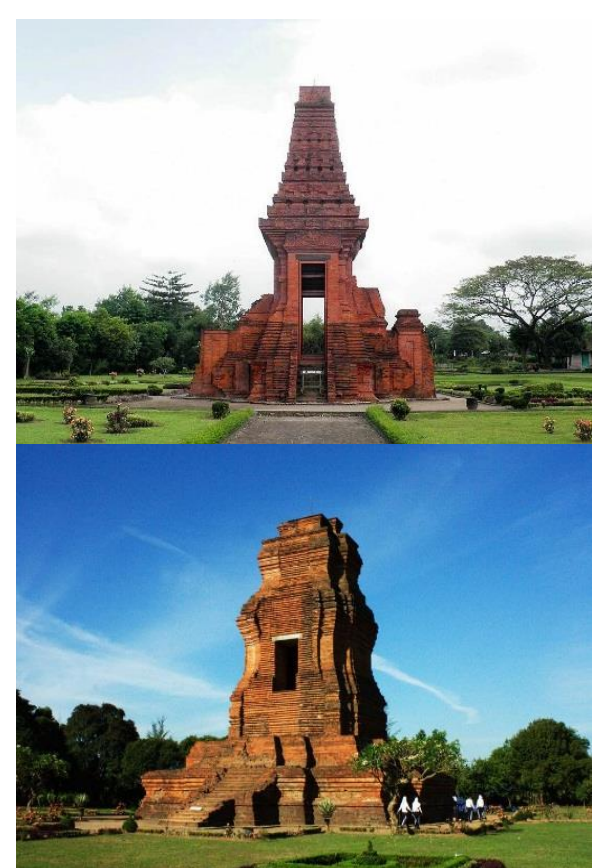

Gambar 16. Candi Bajang Ratu (kiri) dan Candi Brahu (kanan)

\section{c. Tipologi C}

Tipologi C merupakan pengelompokkan obyek wisata yang belum atau tidak dikelola oleh suatu instansi atau lembaga. Obyek wisata pada tipologi $\mathrm{C}$ berada pada tahap exploration. Obyek wisata yang berada pada tahap exploration berjumlah 36 . Obyek wisata tersebut cenderung berkembang dan bertumbuh secara bebas dengan sumber daya yang

\section{SIMPULAN DAN SARAN}

dimiliki dan belum terkelola dengan baik. Obyek wisata pada tahap ini merupakan suatu tempat, arca, bangunan, situs, dan peninggalan yang dapat digali sebagai potensi wisata baru. Jumlah pengunjung yang mengunjungi obyek-obyek wisata tersebut masih sedikit. Obyek wisata tersebut diminati sejumlah kecil wisatawan yang memiliki tujuan tertentu seperti berziarah ke makammakam maupun sekedar menikmati pemandangan alam.

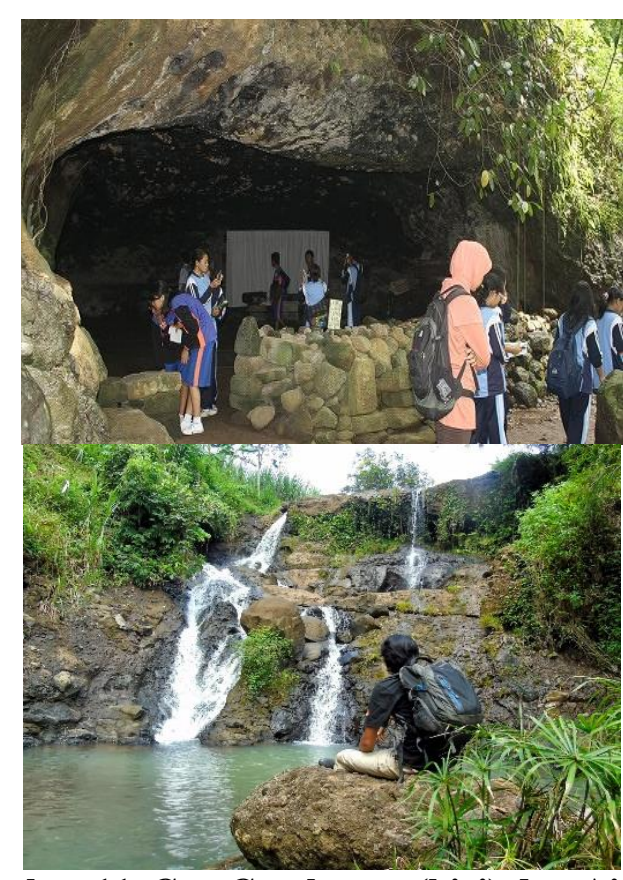

Gambar 11. Goa Gembyang (kiri) dan Air Terjun Grenjeng (kanan)

Mayoritas obyek wisata yang dikelola oleh Pemda Mojokerto (Tipologi A) berada dalam tahap involvement dan development. Artinya, sudah ada pengembangan atraksi wisata yang dimiliki, dilengkapi dengan fasilitas penunjang pariwisata dan produk wisata, serta ada peran serta pihak luar dalam pengelolaannya. Sebagian kecil diantaranya berada dalam tahap exploration dan decline. Mayoritas obyek wisata yang dikelola oleh non Pemda Mojokerto (Tipologi B) berada dalam tahap development. Sebagian besar merupakan benda-benda purbakala peninggalan jaman Kerajaan Majapahit yang dikelola oleh BPCB Jawa Timur. Sebagian kecil diantaranya berada dalam tahap involvement. Obyek wisata yang belum/tidak dikelola oleh lembaga atau instansi tertentu (Tipologi C) berada dalam tahap exploration. Artinya, masih tersedia atraksi alami, belum dilengkapi fasilitas penunjang pariwisata, dan belum banyak diketahui orang sehingga jumlah pengunjung sedikit.

Berdasarkan hal tersebut maka saran yang dapat diberikan untuk menentukan arahan pengembangan 
kawasan wisata di Kabupaten Mojokerto adalah sebagai berikut:

- Obyek Wisata Tipologi A: mengembangkan atraksi wisata buatan untuk mendukung atraksi alami, memberdayakan dan menambah peran serta masyarakat dalam pengelolaan kawasan wisata, serta menarik lebih banyak investor / pihak swasta untuk turut terlibat dalam pengembangan kawasan wisata.

- Obyek Wisata Tipologi B: menambah sarana dan prasarana pendukung kegiatan pariwisata, melakukan promosi wisata, serta mulai melibatkan masyarakat dan pihak swasta dalam pengelolaan kawasan wisata.

- Obyek Wisata Tipologi C:mengembangkan atraksi alami yang dimiliki, memberikan kemudahan aksesibilitas, dan melibatkan masyarakat dalam menyediakan jasa pariwisata.

\section{Daftar Rujukan}

Azwar, Saifuddin. 1998. Metode Penelitian. Yogyakarta: Pustaka Pelajar.

Butler, R.W. 1980. The Concept of a Tourism Area Cycle of Evolution: Implications for Management Resources. The Canadian Geographer, 24(1), 5-16.

Cooper C., et. al. 1998. Tourism: Principles and Practise (2 ${ }^{\text {nd }}$ Edition). New Jersey: Financial Times / Prentice Hall.

Cooper C., et. al. 2005. Tourism: Principles and Practise ( $3^{\text {rd }}$ Edition). New Jersey: Financial Times / Prentice Hall.

Foster, Dennis. 1990. First Class: an Introduction to Travel and Tourism (2 ${ }^{\text {nd }}$ Edition). New York: Glencoe/McGraw-Hill.
Yoeti, Oka. 1997. Perencanaan dan Pengembangan Pariwisata (Cetakan 1). Jakarta: Pradnya Paramita, 1997 xxv, 211 p. : ill., maps ; $21 \mathrm{~cm}$. 